\title{
Innovation of Public Services at Disdukcapil (Population and Civil Registry Office) at Palembang District
}

\author{
Dyah Lituhayu ${ }^{1}$, Maesaroh $^{2}$ \\ \{lituhayudyah@yahoo.co.id $\left.{ }^{1}\right\}$ \\ Universitas Diponegoro, Indonesia ${ }^{1,2}$
}

\begin{abstract}
The objectives of this research are to describe public services related to the population database and to analyze the factors that contribute to innovation in Disdukcapil Palembang. The method used in this research is descriptive qualitative. Disdukcapil Palembang has ever received awards from the Ministry of Administrative and Bureaucratic Reform (RBPAN) as a Role Model because some of the Indicators from the RBPAN have been fulfilled in the Office of Population and Civil Registry Service. There are several indicators which were assessed such as standard service, Information Service, Lactation Room, and Playground. After being assessed by RBPAN, all indicators were fulfilled and Disdukcapil Palembang had been receiving award for three years. The first year was in good category, the second years afterwards was very good in 2017-2018 with 'A' category. The innovations done by the Head Officer to make the service more effective was by giving policy to form UPTD (Technical Implementing Service Unit), so that from 9 sub-districts, each UPTD was formed ( 9 zones). There were 2 sub-districts joining one UPTD. The official of UPTDs are still the UPTD caretaker who is given the authority to do services due to the long distance which become an obstacle if they commute to the Disdukcapil. Service efforts are carried out by both civil servant and non-civil servant every week. They do a mutual cooperative working with the Mayor of Palembang to keep the service opened on each week by picking up system (taking initiative to ask society). The target location is usually at the District Office by rolling schedule or moving system every week which is so called IWAK MELOK GR which stands for "IKut WAli Kota Gotong Royong" (Joining the Mayor to have a Mutual Cooperation).
\end{abstract}

Keywords: Innovation, UPTD, IWAK MELOK.

\section{Introduction}

Improving public services is a bureaucratic challenge in each region, and in order to improve services, the government must have the courage to innovate. This is in accordance with the policies issued by the Ministry of RBPAN [1], it has been applied since 2014 that the year 2014 was the year of public service innovation.

There are several criteria that must be put as the consideration in public service standards based on Menpan Decree Number 25 in 2004 covering service procedures, time of completion, service costs, service products, facilities and infra structure, and staff competence. 
People's complaints about the low-quality service are the indicator of inadequacy services provided by the bureaucratic servants. The community's demand is the challenge for the bureaucracy to provide good services. One of the most important public services for the community is population services including e-KTP, Birth Certificate etc.

One of the problems faced by Palembang citizenships "I lost my ID card; I have filled the requirements to replace it at Disdukcapil. I asked the staff but the problem is unsolved. There are various reasons such as unavailable blanks but they do not know when it is available again, they asked to wait. The staff said when the blanks are available; it will be dropped at the district office" (Disdukcapil Palembang reported).

Basically, every human being, starting from birth to death, always deals with population administration due to the importance of personal data as the citizen. Population administration data cannot be considered unimportant because nearly all aspects of human always need and always require administration related to personal identity.

In fact, there are many people who have not realized the importance of population administration in life. The implementation of population services and civil registration is regulated in Law Constitution Number 23 in 2006 [2]. There are many cause factors that the citizens are careless for their population data. One of them is because the service given has not been maximized and takes time. This case is also happened in Palembang. Though the service is getting better by years, there is still problem in waiting and queuing (Detak Palembang newspaper, 2019). Hence, to overcome those kinds of problems, the government should have innovation of its services.

\section{Methods}

This research is a qualitative descriptive research. The object of the research is Disdukcapil Palembang District. The purposive sampling is used in this research. The informant chosen is based on characteristic considered as the person who knows the most about what the researcher wants [3].

\section{Finding and Discussion}

\subsection{Public Services}

Improving public services is becoming a challenge for the bureaucracy in this globalization era and industry. This happened because the bureaucracy must carry out various kinds of innovations in accordance with the demands of the public. Public service is defined as a mean to fulfill what public want and need which is accomplished by the state organizers $[4][5][6]$.

One of the services that need to be improved is population administration services, because population data is the most essential data for the community. Population administration services are the government responsibility. In order to achieve it, the government bureaucracy must innovate the service maximally.

Research on population services has been done by Dhesti Widya N. [7] at Sumedang Disdukcapil. She found that the level of service got the lowest score compared to other elements [7]. 
The results of this study indicate that Palembang Disdukcapil has improved and innovated in population administration services. One form of service provided is giving certificate or letter of statement as the exchange for E-KTP blanks which is unavailable.

Furthermore, the sign of the service improvement is by receiving the award from Ministry of RBPAN in 2017 as the ROLE MODEL in the service sector. Disdukcapil manages more than a hundred forms every day. Because those many forms were not enough for supply, temporary certificates or letter of statements were given to citizens as an effort to overcome this problem. Then in the future, UPTD will be formed in 18 districts. However, because the license could not be done altogether at one time, it will only be opened in 9 Sub-districts. If it didn't accommodate the citizen needs, the UPTD will be added. Besides, the definitive officials will be placed in each sub-district, so the service of Disdukcapil will no longer be centralized. The signatories are different from those in the village. The only person who must sign the Family Card (KK) are civil registry officials, the Head of Service or the Head of UPTD. The aim of establishing UPTD in each district is to avoid centralized service only in a small office, so that there won't be any queue. Moreover, the requirement of signing the family card should be the head of Registry Service Officer and the sub-district head is not allowed to sign the document. Thus, this UPTD has been prepared, because it is waiting for this Registry Service Officer to be ratified. The duty of this caretaker of Registry Service officer is different from other agencies because the decree is direct from Jakarta, the Mayor proposes 3 to be ratified by Director General 1. While waiting for it, there is local official caretaker. This caretaker must not sign the document, so the citizen should go to the Registry Service Office. There are about 2000 Family Cards that must be brought to Registry Service Office in a day. So, the Family Cards will be distributed to the caretaker to get signed by 9 Officers.

Role Model Award is achieved because of several indicators from the RBMENPAN have been fulfilled at the Population and Civil Registry Service. There are several indicators assessed such as standard service, Information Service, Lactation Room, and Playground. After being assessed by RBPAN, all indicators were fulfilled and so it has been 3 years receiving award. The first year was in good category, the 2 years afterwards was very good category in 2017-2018 with 'A' label. So, this is the indicator of RBPAN in conducting the Role Model assessment.

The UPTD that was formed was different from the heads of other UPTD. These UPTD could sign for its UPTD area or the location of the UPTD. It could also sign the documents throughout Palembang in order to give better service and to get closer to the citizen. It is more efficient and there is no cost. It is hoped to reach the village level. However, it must be supported with good facilities and infrastructure. The best services in the Registry Service Office were tried to be accomplished. Not all the citizen demands can be served because there are procedures and conditions (such as documents that must be fulfilled) as there will be legal problems deal with it. The service hour usually opens at half past 8 in the morning. This service is considered to be the Disdukcapil awareness of the geographical conditions that the Disdukcapil office is very far from the village or sub-district. It often becomes a complaint from the public. Thus, the service model that has been given to overcome the obstacle is the formation of this UPTD.

Based on the observation in the field, it was found that there was a special service for persons with disabilities (Counters for the Disabled), such as providing separate counter. This is an important criterion in assessing value of public services. By providing those kinds of things such as the separated counter for disabled, playground for children, the public service unit could give optimum service. Moreover, there should be an elevator for disabled because 
the building is multi-stories. The disabled must also be able to go to those floors above. Because of the limited funds, we can only prepare the counters first, so that all the elements have been fulfilled.

\subsection{Innovation}

Actually, the concept of bureaucratic innovation and public service is a relatively new concept in the public administration literature. The results of David Mars's research in Lee (1970) revealed that until 1966 there were no publications of public administration writings that discussing about innovation. There was article which discussing about innovation reform entitled "Innovation in Bureaucratic Institution" by Diamant [1][8].

Korea's experience showed that the application of state innovations has improved the quality of governance at the local level. As in Korea, the success of implementing innovation has also happened in China. It has been considered as part of the Chinese tradition [9] quoted from Larasati [10].

While the results of research conducted in Disdukcapil related to the innovation is through picking up the target (taking initiative to ask people) that involves all government SKPD so round Palembang. This picking up service is actually the effort of entire Palembang municipal government ranks which carried out mutual cooperation every week done by both civil servants and non-civil servants together with The Mayor of Palembang to keep the service opened every week with a picking up system throughout the cooperative area. This mutual cooperation is carried out at sub-district level, rotating or moving to each sub-district so that all SKPD can listen to or have dialogue with related citizen or the community, having continuous participation for those who want to make both birth certificate and personal identity. The location is usually held at the District Office and takes turn or moves every week. This activity is so called IWAK MELOK GR which stands for "IKut WAli Kota Gotong Royong" (Joining the Mayor to have a Mutual Cooperation). The picking up system model which is carried out as a follow up from Disdukcapil goals to keep maintaining the award as a role model that needs to be proven to the public due to the consistency in providing good public services. Further aspect that we need to improve is the digital or online services, because it will be useful innovation such as signing the document from the service center just through electronic signatures.

The innovation that has not been implemented due to the wideness of Disdukcapil area is this office's authority. The lack of facilities becomes the responsibility of the office, the mayor, and the regional house of representative (DPRD) because they have the authority to propose better location.

\section{Conclusion}

Based on the research results conducted in Disdukcapil related to innovations, it can be concluded:

a) In order to improve the services, various efforts have been completed especially in taking action as a respond to the difficulty in getting e-KTP (electronic personal identity) blanks which truly depend on the central government. By giving the citizen temporary certificates or letter of statements which valid for 6 months since it is first launched while 
waiting for the blanks delivered from the central government. This case is not only happened in Palembang but also happened all regions in Indonesia.

b) Innovation has been carried out as an effort to prove as well as to maintain the achievement of becoming a role model. The aim of innovation is to overcome distance matter caused by the geographic condition. So that people can easily get the signature at UPTD and reduce transportation costs.

c) To reach a maximal service, the innovation was done through IWAK MELOK GR (Joining the Mayor to have a Mutual Cooperation) which has been conducted by the Major to take turn or move every week throughout the district in Palembang. Meanwhile, Disdukcapil always provides service car as the transportation during picking up system from one district to others. This is an effective way to minimize citizens' transportation cost.

d) Another form of innovation carried out by Disdukcapil is through online service model so that it accelerates the service process more quickly. However, this innovation has not been maximally implemented because there are still some obstacles, both from the technical and non-technical constraints.

e) The commitment of Mayor and head service officer to maintain a predicate as a role model becomes a motivation to always improve services. There is a good commitment that is always carried out by the head of service and his staff.

f) The innovation has been reduced of transportation cost for societies.

\section{References}

[1] K. dan RB, Kumpulan Praktek Baik Inovasi Pelayanan Publik Jilid 2. .

[2] "UU No 23 Tahun 2006 tentang Administrasi Kependudukan.".

[3] M. B. Miles, A. M. Huberman, M. A. Huberman, and M. Huberman, Qualitative data analysis: An expanded sourcebook. sage, 1994.

[4] S. L. Poltak, "Manajemen Sumber Daya Manusia, Penerbit PT," Bumi Aksara, Jakarta, 2016.

[5] N. Achmad, "Manajemen pelayanan publik," Penerbit. PT. Sinergi Visi Utama, Yogyakarta. Cet-Pertama, 2010.

[6] N. Suparman, "Evaluasi Kebijakan Pelimpahan sebagian Kewenangan Bupati kepada Camat di Kecamatan Sagala Herang Kabupaten Subang Tahun 2015,” Polit. Indones. Indones. Polit. Sci. Rev., vol. 2, no. 2, pp. 159-178, 2017.

[7] D. W. N, "Public services at Sumedang DISDUKCAPIL," 2017.

[8] W. Kumorotomo, Governance Reform di Indonesia: Mencari arah kelembagaan politik yang demokratis dan birokrasi yang profesional. Penerbit Gava Media, 2009.

[9] O. Shenkar, The Chinese century: The rising Chinese economy and its impact on the global economy, the balance of power, and your job. Pearson Education, 2006.

[10] E. L. Dkk, Inovasi Pelayanan Publik. Semarang: Undip Law Press, 2016. 